\title{
Mycorrhiza and Phosphate Solubilizing Bacteria: Potential Bioagents for Sustainable Phosphorus Management in Agriculture
}

Fazli Wahid ${ }^{1}$, Muhammad Sharif ${ }^{2}$, Shah Fahad ${ }^{3}$, Amjad Ali $^{4}$, Muhammad Adnan $^{1}$, Rafiullah ${ }^{1}$, Shah Saud ${ }^{5}$, Subhan Danish ${ }^{6,}$, Muhammad Arif Ali ${ }^{6}$, Niaz Ahmed ${ }^{6}$, Hüseyin Arslan ${ }^{7}$, Doğan Arslan ${ }^{8}$, Murat Erman $^{8}$, Ayman EL Sabagh ${ }^{8,9, *}$, Fatemeh Gholizadeh ${ }^{10}$ and Rahul Datta ${ }^{11}$

${ }^{1}$ Department of Agriculture, University of Swabi, Swabi, 23561, Pakistan

${ }^{2}$ Department of Soil and Environmental Sciences, The University of Agriculture, Peshawar, 25130, Pakistan

${ }^{3}$ Department of Agronomy, The University of Haripur, Haripur, 22620, Pakistan

${ }^{4}$ School of Environmental and Municipal Engineering, Xi'an University of Architecture and Technology, Xi’an, 710055, China

${ }^{5}$ Department of Horticulture, Northeast Agricultural University, Harbin, 150030, China

${ }^{6}$ Department of Soil Science, Faculty of Agricultural Sciences and Technology, Bahauddin Zakariya University, Multan, 60800, Pakistan

${ }^{7}$ Department of Field Crops, Faculty of Agriculture, Harran Üniversity, Osmanbey Campus, Şanliurfa, 63050, Turkey

${ }^{8}$ Department of Field Crops, Faculty of Agriculture, Siirt University, Siirt, 56100, Turkey

${ }^{9}$ Department of Agronomy, Faculty of Agriculture, Kafrelsheikh University, Kafrelsheikh, 33156, Egypt

${ }^{10}$ Department of Plant Production and Genetics, Faculty of Agriculture, University of Kurdistan, Sanandaj, 66177-15175, Iran

${ }^{11}$ Department of Geology and Pedology, Faculty of Forestry and Wood Technology, Mendel University in Brno, Brno, 61300, Czech Republic

*Corresponding Authors: Subhan Danish. Email: sd96850@gmail.com; Ayman EL Sabagh. Email: ayman.elsabagh@agr.kfs.edu.eg

Received: 14 March 2021 Accepted: 31 May 2021

\begin{abstract}
Phosphorus $(\mathrm{P})$ is a critical nutrient that plays an essential role in improving soil fertility for optimum plant growth and productivity. It is one of the most deficient macro-nutrients in agricultural soils after nitrogen and is considered inadequate for plant growth and production. To $\mathrm{P}$ availability in soils, the farmers are applying huge amounts of synthetic $\mathrm{P}$ fertilizers that adversely affect the wider environment, groundwater, soil fertility and microbial population. Many beneficial microbes are known to release and supply soluble $\mathrm{P}$ for improving growth and yield of a variety of plants in a sustainable manner in $\mathrm{P}$ deficient soils. Thus, inoculation of these microbes, including arbuscular mycorrhizal fungi (AMF) and phosphate solubilizing bacteria (PSB) to soil to enhance crop production without harming the environment, is an alternative approach to chemical fertilizers. The combined role of AMF and PSB in P solubilization is not well understood and the application and mode of action of these microbial groups are often naive due to variation in the environment. Therefore, the current review article would develop a better understanding of the interactive role and mechanisms of AMF and PSB in improving P availability from both organic and inorganic sources in a sustainable crop production system. Finally, the current review would loop out further avenues for researchers interested to commercially produce effective AMF and PSB-based biofertilizers for sustainable management of phosphorus over a wide range of agricultural crops worldwide.
\end{abstract}




\section{KEYWORDS}

Beneficial microbes; soil inoculation; phosphorus; mineralization; crop production

\section{Introduction}

Phosphorus $(\mathrm{P})$ is the second most essential nutrient required for plant growth after nitrogen across the global agricultural lands [1]. Therefore, a sufficient available amount of this nutrient is needed for sustainable crop production. It is not only a part of nucleic acids, ATP and phospholipids [2], but also it adjusts to plant enzymatic reactions and metabolic processes like photosynthesis, signal transduction and respiration [3]. Although P plays a critical role in plant productivity, its soil reserves (organic and inorganic forms) have limited supply to plants due to fixation and complex formation with other soil nutrients [4]. Consequently, heavy doses of high-cost $\mathrm{P}$ fertilizers are applied to $\mathrm{P}$ deficient soils to supply adequate $\mathrm{P}$ for maximum plant productivity and food security to the world's growing population [5]. Phosphatesolubilizing bacteria enhance Oryza sativa growth and nutrient accumulation in an oxisol fertilized, but meanwhile, it has also increased environmental risks. For example, it has affected human health, agricultural products [6], soil microbiota, fiber yield and soil fertility [7]. Therefore, to avoid the danger of these chemical fertilizers in the wider environment, the scientific community is trying to adopt environmentally friendly, economically viable, safe, and sustainable soil fertilization methods for P solubilization and plant growth [8]. In this scenario, the inoculation of beneficial microbes has become of paramount importance in the agricultural sector for their potential role in food safety and sustainable crop production. Furthermore, the application of these microbes as biofertilizers has been adopted as a very useful approach to providing the plants with their nutritional requirements without having an undesirable impact on the environment $[9,10]$.

In agricultural sustainability, the use of beneficial microbes like arbuscular mycorrhizal fungi (AMF) and phosphate solubilizing bacteria (PSB) for P solubility and crop productivity is getting more attention [1117]. These microbes take part in the turnover and bioavailability of insoluble soil nutrients through different functional processes $[18,19]$. With regard to plant health and promotion, the commonly found beneficial microbes such as bacteria and fungi are very important [20]. The phosphate solubilizing bacteria (PSB) have been used for crop growth and production since 1903 because it improves the solubility of $\mathrm{P}$ fertilizers and soil-bound $\mathrm{P}$ in such a way to make them available for plants [21]. Plant roots and their rhizosphere provide food, energy, shelter, and biological diversity to PSB [22]. Thus, PSB promote crop productivity, resistance to diseases, protection against insect damages, inoculants production and stability of the ecological environment [23]. In addition to P availability and supply to plants, PSB can be used for the bioremediation of polluted soils [24].

Apart from PSB, different mycorrhizal associations have also been identified based on the type and structures in rhizosphere soil [25]. The AMF is an important mycorrhizal association and it has been found that it can colonize about $80 \%$ of all terrestrial plants [26]. The AMF account for 5-50\% of the biomass of soil microbes and are mostly found in agricultural soils [27] and establish their mutualistic association with agricultural, horticultural and hardwood crop species [28]. Colonization of roots by AMF has been shown to improve the growth and productivity of several field crops [29,30]. Arbuscular mycorrhizal fungi can be found extensively in different environmental conditions and form a mutual association with several legumes and forage crops [31].

In natural and agricultural ecosystems, arbuscular mycorrhizal fungi in relation to rhizobacteria boost $\mathrm{P}$ availability, plant growth and productivity is relatively of a recent development. The interaction of AMF with certain plant growth-promoting rhizobacteria (PGPR) enhances the activity of AMF and P, Zn and Cu uptake 
by maize crop [18,32]. These microorganisms have the potential to solubilize inorganic phosphate and supply nutrients in a readily available form [11]. It has been found that PSB constitute $1 \%$ to $50 \%$, while AMF are accounted for $0.1 \%$ to $0.5 \%$ in phosphorus availability and solubility [33]. The dual inoculation of AMF with PSB has also proved significant effects on increasing plant growth, root-shoot dry weight, available $\mathrm{P}$ concentration, $\mathrm{pH}$ and electrical conductivity (EC) of both the bulk and rhizosphere soil [34].

Similarly, the interaction of AMF and PSB has also been observed in increasing crop performance, inorganic $\mathrm{P}$ fraction and changes in biological population. Likewise, the population density of AMF and PSB has been confirmed in post-harvest soil [35]. The bacteria with $\mathrm{P}$ solubilizing ability has also been found to change the growth of mycorrhizal fungi in roots (outside and inside) in the presence of soil native microbes [36].

The synergistic role and mechanisms between AMF and PSB in P solubilization from different organic and inorganic sources are not well understood. Moreover, the application of both these microbial groups is often naive due to variation in the environment (biotic and abiotic). Therefore, the current review article aims to understand the single and interactive role of AMF and PSB on P solubilization from different sources for sustainable crop production. Furthermore, the current review would loop out further avenues for researchers interested to commercially produce the PSB and AMF based biofertilizers to be effective in P management over a wide range of crops.

\section{Soil Phosphorus and Its Available Sources}

\subsection{Soil Phosphorus Contents and Its Availability to Crops}

Globally, the natural soil reserves of phosphorus (P) are depleting at a higher rate and it has been estimated that there will be very limited soil P reserves by the end of 2050 for crop growth and sustainability, especially in the tropical and subtropical regions of the world [37,38]. A large amount of $\mathrm{P}$ is present both in organic and inorganic forms in soil, but only a small proportion is available for plant uptake and the remaining is mostly restricted with other soil nutrients due to complex formation [39-41]. For plant growth, the amount of soil solution $\mathrm{P}$ pool is very small compared to overall soil $\mathrm{P}$, as evident in alkaline soils, sandy soils and weathered soils of tropical and subtropical regions. Furthermore, $30 \%$ to $50 \%$ of total $\mathrm{P}$ is present in organic form in soil and thus not available for the direct use of the plants [42]. The P deficiency can be found mainly in the agricultural soils of developing countries, having an unfavorable condition for P availability and uses by the plants [43]. It is predicted that more than $40 \%$ of the world soils are $\mathrm{P}$ deficient and has limited crop growth and production [44]. The total amount of $\mathrm{P}$ in the soil is $0.05 \%$, only $0.1 \%$ (Fig. 1 ) of this is available for the plant's growth. The type and $\mathrm{pH}$ of the soils are essential factors for the determination of $\mathrm{P}$ fixation and precipitation with $\mathrm{Fe}$ and $\mathrm{Al}$ at acidic soils and $\mathrm{Ca}$ in alkaline calcareous soils [45].

Moreover, physical adsorption and chemical precipitation are also responsible for the $\mathrm{P}$ fixation with $\mathrm{Fe}$ and $\mathrm{Al}$ oxides and hydroxides in acidic soils [46]. Consequently, after P fertilization, only $30 \%$ to $40 \% \mathrm{P}$ is recovered by the plants and the rest is adsorbed, precipitated and forms complexes with other soil nutrients [47]. In soil, the common organic forms of P (Fig. 1) are phosphomonoesters and phosphodiesters, including phospholipids, nucleic acids, sugar phosphate, glycerophosphate and coenzymes [48]. These forms of P must be converted into inorganic $\mathrm{P}$ before used by the plants. Plants fulfil their requirements by utilizing inorganic $\mathrm{P}$ from soil solution as phosphate anions after mineralization of organic $\mathrm{P}$ [49]. Most of the soil organic $\mathrm{P}$ compounds are present as high molecular weight. Therefore before plant uptake, these compounds must be converted into low molecular weight or soluble P [50]. 


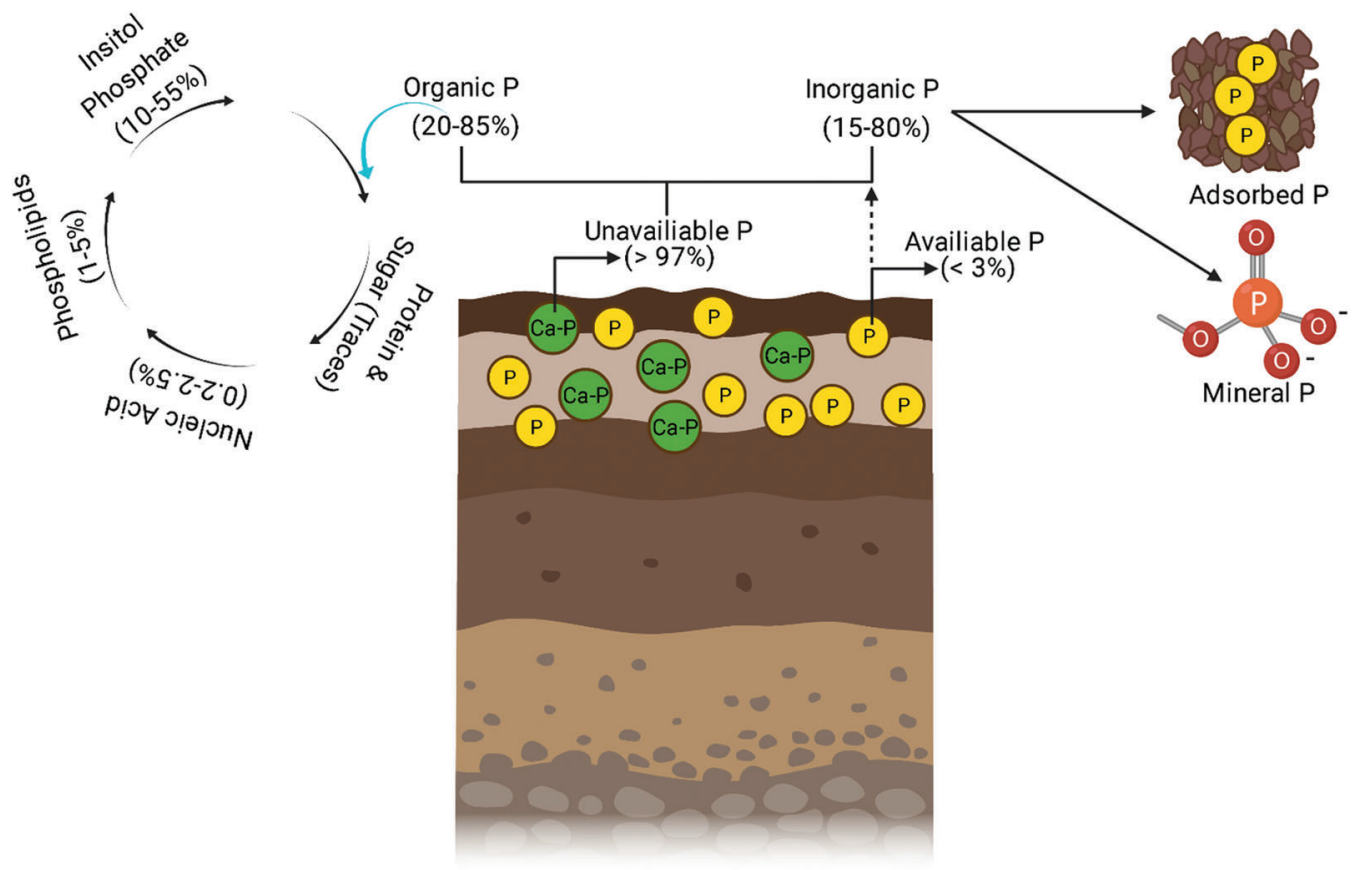

Figure 1: Soil $\mathrm{P}$ contents and their forms in the soil

Source: https://www.slideshare.net/DileepKumar9535017438/phosphorus-dynamics-in-calcareous-soils-with-respect-to-crop-growth.

Phosphorus is an essential macronutrient like Nitrogen $(\mathrm{N})$ and Potassium $(\mathrm{K})$, which is vital for many plant growths processes. For the normal function and growth promotion of crops, approximately $10-25 \% \mathrm{P}$ is required [51]. Plants absorb $\mathrm{P}$ mainly during the vegetative stage and then re-translocate it to the fruits and seeds at the reproductive stage. Phosphorus is involved in various cellular functions [52] and its deficiency causes dark green coloration anthocyanin formation [3]. Plants absorb P from the soil solution as primary orthophosphate or secondary orthophosphate. If the orthophosphate of soil solution is not enough to fulfil the plant's requirements, then it is replenished from other pools of soil P [53]. Moreover, exchange and depletion of orthophosphate also occur between the rhizosphere and bulk soil present in the vicinity of the plant roots [54]. The different microbial processes in the mycorrhizosphere are also responsible for the transformation of $\mathrm{P}$ to the roots surface and their uptake by the plants [55].

\subsection{Chemical Fertilizers as a Source of Phosphorus}

Another important source that fulfills the deficiency of $\mathrm{P}$ in soil is the different types of chemical fertilizers. The important chemical fertilizers, which are commonly used as a source of $\mathrm{P}$ in Pakistan are Di-ammonium phosphate (DAP), Triple Super Phosphate (TSP), Single Super Phosphate (SSP) and Nitrophos (NP) containing 46\% $\mathrm{P}_{2} \mathrm{O}_{5}, 30 \% \mathrm{P}_{2} \mathrm{O}_{5}, 14-18 \% \mathrm{P}_{2} \mathrm{O}_{5}$, and $23 \% \mathrm{P}_{2} \mathrm{O}_{5}$, respectively [56]. The amount of nutrients in the chemical fertilizers sources is quite high, with an easily transferable capacity to soil and quick uptake by plants. The application of chemical sources of $\mathrm{P}$ fertilizers in the field and greenhouse conditions is also easy and requires less labor cost. The $\mathrm{P}$ content of chemical fertilizers fulfils the nutrients requirement of the crop. However, at high $\mathrm{pH}(8.5)$, it is also adsorbed with surface containing calcium compounds, decreasing its availability to crops from inorganic sources like Single Super Phosphate [57]. According to Khan et al. [58] when the inorganic P fertilizers are added to the soil, than about $85-90 \%$ become unavailable for the plant's uptake. This is due to adsorption and precipitation with $\mathrm{Ca}$ and $\mathrm{Mg}$ at alkaline soil conditions and $\mathrm{Al}$ and $\mathrm{Fe}$ at acidic soil conditions in the same year of application. Besides, the quick source of $\mathrm{P}$, the huge supplementation of chemical fertilizers to the soil 
also causes several adverse impacts like water resources pollution, changes in soil $\mathrm{pH}$ due to acidity and alkalinity, insects and microbe's destruction, soil degradation due to high organic matter decomposition and nutrients fixation [33]. The high prices of chemical fertilizers in the national market of Pakistan have compelled the farmers to reduce the dosage of chemical fertilizers in their fields, which resulted in low crop yields. Compared to 2006-2007, the high prices of chemical fertilizers in 2008-2009 and 20092010 caused that, the usage of chemical fertilizers was decreased to $35 \%$ and $53 \%$, respectively. Similarly, the cost of urea, DAP, CAN and NP during 2011-2012 jumped up to $81 \%, 39 \%, 76 \%$ and $46 \%$, respectively, as compared to prices of these fertilizers in the year 2010-2011 [59]. The high transportation cost and prices of importing chemical fertilizers in developing countries have changed the farmer's opinion to adopt environmentally friendly indigenous sources of fertilizers like rock phosphate $[59,60]$ or other options like biofertilizers, organic manures, and composts to meet the nutrient requirement of the crop plants.

\subsection{Rock Phosphate (RP) as a Source of Phosphorus}

The estimated resources of all grades and types of rock phosphate (RP) are approximately 163,000 million tons [39,40,61]. The world RP reserves (Tab. 1) are distributed in Africa (41\%), USA (21\%), USSR (13\%), Middle east (10\%), Asia (8\%), South America (3\%), Australia (2\%) and Europe (1\%) [59,61]. However, the RP scenario in Pakistan is also prominent. It is estimated that there are million tons of recoverable RP deposits in the Hazara district of Khyber Pakhtunkhwa. Therefore, they are cheap available sources of $\mathrm{P}$ fertilizers for sustainable crop production. The origins of these RP deposits are the sedimentary rocks distributed in an area of approximately $155 \mathrm{~km}^{2}$ at different localities. In this area, the total predictable RP reserves are about 6.9 million tons; 4.59 million tons of that amount are recoverable and can be used in alkaline soils as a potential source of P fertilizer [62]. The different localities having RP deposits are Kakul, Lagarban south, Eastern phosphorite, Batkanal and Southern phosphorite containing $0.6,1.34,1.54,0.6$ and 0.495 million tons RP, respectively. Moreover, Lagarban is the major RP deposit in Pakistan, containing an average of $25.8 \% \mathrm{P}_{2} \mathrm{O}_{5} \%$ and $6 \% \mathrm{MgO}$.

Table 1: Rock phosphate reserves of the world

\begin{tabular}{lll}
\hline Countries & IFDC Reserves (product) (Mmt) & IFDC (Resources) (Mmt) \\
\hline USA & 18,000 & 49,000 \\
Australia & 82 & 3500 \\
Brazil & 400 & 2800 \\
Canada & 5 & 130 \\
China & 3700 & 16,800 \\
Egypt & 51 & 3400 \\
Israel & 220 & 1600 \\
Jordon & 900 & 1800 \\
Morocco & 51,000 & 170,000 \\
Russia & 500 & 4300 \\
Senegal & 50 & 250 \\
South Africa & 230 & 7700 \\
Syria & 250 & 2000 \\
Togo & 34 & 1000 \\
Tuinisia & 85 & 1200 \\
Other countries & 600 & 22,000 \\
Total & 60,000 & 290,000 \\
\hline
\end{tabular}

Notes: IFDC: www.ifdc.org; Mmt: million metric ton; Reserves: usable or marketable products; Resources: unprocessed rock phosphate of varying grades concentration. 
The repeated use of chemical fertilizers in large amounts is expensive, and it adversely affects the environment and soil microbial populations $[60,63]$. Therefore, naturally occurring rock phosphate (RP) is a cheaper and environmentally-friendly alternative source than the commercial P fertilizers [64]. It is used in industry as a raw material in the manufacture of $\mathrm{P}$ fertilizers such as SSP, DAP and NP. Moreover, the direct use of RP as a source of $\mathrm{P}$ fertilizer is agronomically more suitable for alkaline soils in the presence of certain amendments [62]. The four main types of RP are Flouro apatite, Carbonate apatite, Sulpho apatite and Hydroxy apatite. The deposits of sedimentary apatites are soft and microcrystalline in structure, and they are commercially more important to use directly in the soil [65]. Therefore, the direct application of RP at alkaline soils is an important substitute for unaffordable commercial P fertilizers [66].

The poor farmers of west Africa cannot afford the supplementation of expensive commercial $\mathrm{P}$ fertilizers in their soils. Therefore, the direct application of low-cost RP is more suitable against highcost commercial P fertilizers [67]. In soils, factors like soil and climatic conditions, moisture contents, granular size, time and application rate are very important for the release of P from RP [68]. The direct application of RP is common in acid soils because it contains hydrogen ions responsible for converting $\mathrm{P}$ from RP into a water-soluble form. Moreover, the alkaline soils seize the solubility of $\mathrm{P}$ unless enough amount of hydrogen ions are added to them. Organic matter also enhances the solubility of $\mathrm{P}$ due to hydrogen ions in the soils. This is because when organic matter starts decomposition, it releases acids (e.g., Humic acid), which enhance P solubility from RP by lowering the soil pH [69]. Several researchers have proved the financial and agronomic effectiveness of RP application on acidic and alkaline soils for sustainable crop production.

Mashori et al. [70] experimented with alkaline calcareous soil in Pakistan to determine the agronomic effectiveness of local RP in combination with FYM and SSP. Different rates of RP and SSP were applied to all treatments along with or without FYM $\left(10\right.$ tons $\left.\mathrm{ha}^{-1}\right)$. Recommended rates of $\mathrm{N}$ and $\mathrm{K}$ fertilizers were constantly applied to all the treatments as a basal dose. After crop harvesting, plant growth parameters and nutrient concentration were recorded. The maximum shoot dry biomass $\left(30 \mathrm{~g} \mathrm{pot}^{-1}\right), \mathrm{P}$ concentration $(0.31 \%)$ and uptake $\left(0.10 \mathrm{~g} \mathrm{pot}^{-1}\right)$ were noted in the treatment having RP and SSP along with FYM; it was followed by the treatment having RP and SSP alone. They concluded that the integrated use of indigenous RP with water-soluble P fertilizers and FYM was a promising and important substitute for expensive commercial $\mathrm{P}$ fertilizers at alkaline calcareous soils in Pakistan. This was to solve the $\mathrm{P}$ problems and attain maximum crop productivity. The agricultural soils of Indonesia are mostly acidic in nature thus contain a low quantity of both total and available P concentration. At these soils, $\mathrm{P}$ deficiency corrections are crucial for improving soil fertility and plant productivity. Therefore, an experimented was conducted in farmer's fields to evaluate RP's reactive and agronomic- effectiveness on maize crop on an Ultisol at the South Kalimantan Province of Indonesia. In addition, the residual effects of these phosphate rocks were also determined during six cropping seasons. The authors concluded that the reactive RP could be used effectively to enhance fertility and crop growth. Moreover, they also recommended the direct application of RP in P deficient acidic soils in Indonesia [71] (Fig. 2). 


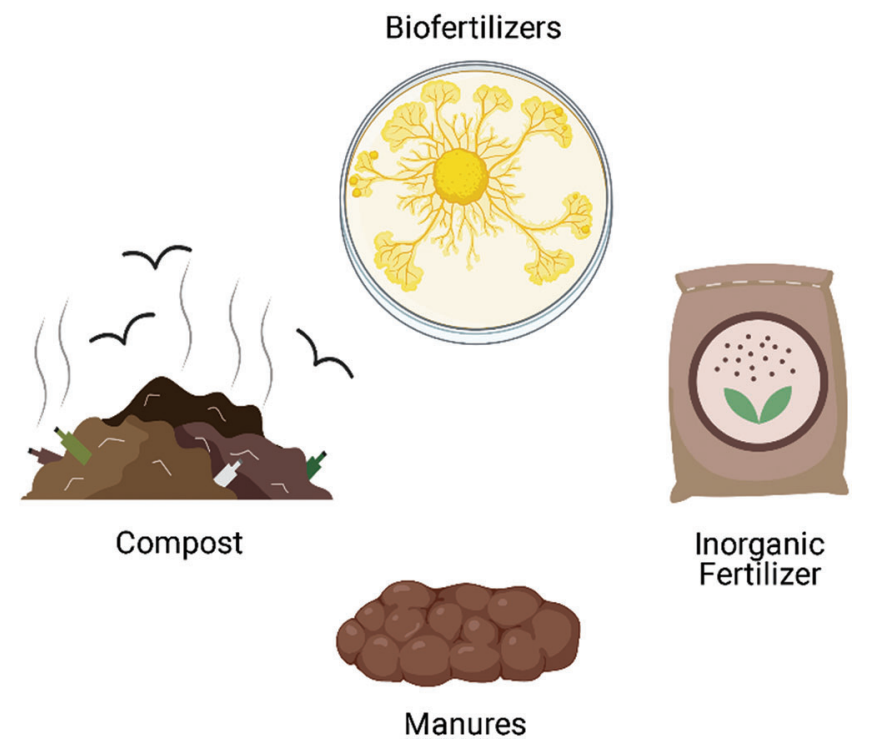

Figure 2: Different sources of phosphorus fertilizers

\section{Beneficial Microbes and Mechanisms for Phosphorus Availability}

\subsection{Phosphate Solubilizing Microorganisms}

The presence of rhizospheric phosphate solubilizing microorganisms (PSMs) and their role in $\mathrm{P}$ acquisition of plants is evidenced since 1903 [21]. Several types of efficient soil microbes have been isolated and identified from the plant rhizosphere (Tab. 2). They solubilize orthophosphate from insoluble and inorganic bound $\mathrm{P}$ and enhance its availability for plants uptake [72,73]. Several bacterial strains such as Bacillus (Bacillus megaterium, B. subtilis, B. circulans B. sircalmous, B. polymyxa), Enterobacter, Rhizobium and Pseudomonas [74] along with Penicillium, Aspergillus, mycorrhizal fungi and actinomycetes fungi are the most powerful $P$ solubilizers [75].

The commonly known PSMs in the rhizosphere are species of free-living fungi and bacteria that help plants in P solubility and bioavailability [40]. In agriculture these PSMs are used as biofertilizers due to their effectiveness in the solubility of fixed $\mathrm{P}$ and its uptake by plants for a sustainable crop production $[35,76]$. Application of phosphate solubilizing microbes to soil can mineralize the wider substrates of organic P [77]. Moreover, the turnover of microbial biomass plays a significant role in retaining the levels of organic and inorganic $\mathrm{P}$ in the soil solution, and is very important for determining a sufficient amount of $\mathrm{P}$ supply to plants [78]. This participation of microbes can be significantly judged in the rhizosphere having an adequate quantity of metabolized $\mathrm{C}$ and a higher population of microbes [79]. The microbial biomass also plays a significant role in the $\mathrm{P}$ cycle in the soil; therefore, the subsequent release is very important for maintaining the pathways and movement of $\mathrm{P}$ in the soil-plant system. Additionally, the PSM can also protect orthophosphate via a complex formation with other soil nutrients due to different physico-chemical properties of the soil [78]. 
Table 2: Phenotypic and microscopic characteristics of PSB colonies isolated from rhizosphere of field crops, vegetables and pastures in selected areas of Pakistan

\begin{tabular}{|c|c|c|c|c|c|c|c|}
\hline \multirow[t]{2}{*}{ Isolates } & \multirow[b]{2}{*}{ Elevation } & \multicolumn{4}{|c|}{$\begin{array}{c}\text { Phenotypic } \\
\text { characteristics }\end{array}$} & \multicolumn{2}{|c|}{$\begin{array}{l}\text { Microscopic } \\
\text { characteristics }\end{array}$} \\
\hline & & Color & Shape/form & Margin & Opacity & Staining & Bacteria shape \\
\hline \multicolumn{8}{|l|}{ Chitral } \\
\hline Maize irrigated & Raised & Yellow & Puncti form & Entire & Translucent & G- & Coccus \\
\hline Maize un irrigated & Flate & Offwhite & Circular & Curled & Translucent & G- & Bacillus \\
\hline Sorghum irrigated & Raised & Offwhite & Puncti form & Entire & Opaque & G- & Coccus \\
\hline Sorghum rainfed & Flate & Offwhite & Circular & Erose & Opaque & $\mathrm{G}+$ & Coccus \\
\hline Onion & Flate & Milky & Filamentous & Entire & Translucent & G- & Streptococcus \\
\hline Spinach & Raised & Offwhite & Irregular & Curled & Translucent & G- & Bacillus \\
\hline Lady finger & Raised & Offwhite & Irregular & Curled & Translucent & G- & Coccus \\
\hline Common Cockle burr & Raised & Reddish & Punctiform & Lobate & Opaque & $\mathrm{G}^{+}$ & Coccus \\
\hline Bermuda grass & Umblicate & Offwhite & Filamentous & Entire & Opaque & G- & Coccus \\
\hline Common cattail & Raised & Offwhite & Filamentous & Curled & Opaque & G- & Streptococcus \\
\hline \multicolumn{8}{|l|}{ Peshawar } \\
\hline Maize irrigated & Flate & Yellow & Punctiform & Entire & Translucent & G- & Streptococcus \\
\hline Maize rainfed & Umblicate & Reddish & Circular & Entire & Opaque & G- & Coccus \\
\hline Sorghum irrigated & Raised & Yellow & Punctiform & Curled & Translucent & G- & Bacillus \\
\hline Sorghum rainfed & Raised & Offwhite & Circular & Entire & Opaque & G- & Coccus \\
\hline Tomato & Flate & Yellow & Punctiform & Entire & Opaque & G- & Bacillus \\
\hline Chilli & Raised & Offwhite & Punctiform & Curled & Translucent & $\mathrm{G}^{+}$ & Coccus \\
\hline Egg plant & Flate & Offwhite & Filamentous & Lobate & Opaque & G- & Bacillus \\
\hline Common Cockle burr & Raised & Offwhite & Punctiform & Curled & Translucent & $\mathrm{G}+$ & Coccus \\
\hline Bermuda grass & Raised & White & Punctiform & Curled & Translucent & G- & Coccus \\
\hline Common cattail & Raised & Offwhite & Umbonate & Curled & Opaque & $\mathrm{G}^{+}$ & Bacillus \\
\hline \multicolumn{8}{|l|}{ D.I. Khan } \\
\hline Maize irrigated & Flate & Offwhite & Punctiform & Erose & Opaque & G- & Coccus \\
\hline Maize un irrigated & Flate & Yellow & Punctiform & Erose & Translucent & G- & Bacillus \\
\hline Sorghum irrigated & Umbonate & Milky & Rhizoid & Curled & Opaque & G- & Streptococcus \\
\hline Sorghum rainfed & Flate & Offwhite & Punctiform & Entire & Translucent & G- & Coccus \\
\hline Tomato & Flate & Offwhite & Filamentous & Entire & Opaque & $\mathrm{G}^{+}$ & Coccus \\
\hline Salad & Flate & White & Punctiform & Curled & Translucent & G- & Coccus \\
\hline Pumpkin & Umblicat & White & Punctiform & Curled & Opaque & G- & Bacillus \\
\hline Barnyrad grass & Raised & Offwhite & Punctiform & Entire & Opaque & G- & Bacillus \\
\hline Prosopasspp & Raised & Offwhite & Rhizoid & Entire & Opaque & $\mathrm{G}+$ & Coccus \\
\hline Common cattail & Raised & Offwhite & Rhizoid & Curled & Opaque & G- & Coccus \\
\hline
\end{tabular}


Several researchers have studied the role of PSM under controlled conditions and suggested that the inoculation of plants with PSM significantly increases growth and P uptake due to their P solubilizing activities in the rhizosphere $[35,80]$. The effect of most of the PSM is different under greenhouse and field conditions. This is due to the effect of many factors such as a complex soil environment, lack of knowledge for introducing soil microbes and their mechanisms, the interaction between microbes in the soil community, and lack of a specific partner for association [49]. For example, Whitelaw et al. [75] reported that Penicillium radicum efficiently solubilized $\mathrm{P}$ and enhanced wheat growth under greenhouse conditions after P fertilization. Sashidhar et al. [81] studied the single and combined inoculation of Bacillus polymyxa, Pseudomonas striata and Aspergillus awamori and found considerable improvement in grains yield of cowpea, soybean, chickpea, rice and lentil.

\subsection{Mechanisms and Role of Arbuscular Mycorrhizal Fungi in Phosphorus Availability to Crops}

About $80 \%$ of all vascular plants or some 250,000 plants species can form a symbiotic association with AMF $[83,84]$. AMF enhanced the uptake of different nutrients such as $\mathrm{P}, \mathrm{Cu}, \mathrm{Fe}, \mathrm{Zn}$ and $\mathrm{Mn}$ from the soil to the host plants $[85,86]$. Arbuscular mycorrhiza improves plant growth and nutrition by exploring the soil located beyond the zone of depletion and take the nutrients present in the depletion zone more efficiently [87]. The AMF transfer P from the soil to the plant at the interface between plant cells and other essential structures like hyphae coils, arbuscules, and vesicles [87]. P transporters are involved in the uptake of $\mathrm{P}$ by AMF to plants cells, which proves that it's an active process in the soil [88]. It has been studied that AMF distribute and absorbs $\mathrm{P}$ more efficiently in tilled soils of wheat and maize crop roots than in notilled soils [89]. The P nutrition is improved both by AMF and some soil physicochemical properties with different tillage treatments [29]. However, the plant's root is colonized by AMF and non-mycorrhizal control in field conditions is difficult to evaluate. Therefore, sometimes it became difficult to get clear proof regarding the significance of AMF in crop nutrition [90]. Mycorrhiza may also contribute a key function in the mineral nutrition of plants by various elements, protecting plants from hazards and absorption of toxic heavy metals, increasing salt tolerance, and increasing the stability of soil aggregates [91]. Naher et al. [92] demonstrated that AMF plays a significant role in agricultural sustainability as well as in the mutualism with plant roots. Moreover, AMF are also important for the uptake of nutrients, to reduce water stress and as a biological protectant against pathogens.

The effect of a commercial mycorrhiza inoculum and indigenous AMF with a phosphate fertilizer on the yield and $\mathrm{P}$ availability of a maize crop was studied by Cozzolino et al. [2] under field conditions. They confirmed that the effect of a commercial AMF inoculum in the $\mathrm{N}$ and $\mathrm{K}$ treatments was almost similar to the treatment having $\mathrm{P}$ in combination with $\mathrm{N}$ and $\mathrm{K}$ fertilizers. After 40 days of the experiment, higher $\mathrm{P}$ concentrations were recorded in $\mathrm{N}, \mathrm{P}, \mathrm{K}$ and $\mathrm{NK}$ treatments. This result shows that the inoculated roots can improve soil and plant $\mathrm{P}$. Moreover, these results also suggest that AMF inoculum is a promising approach for integrated nutrients management in $\mathrm{P}$ deficient soils [93].

Similarly, in a 13-year-old irrigated field experiment in Nebraska, the effect of different rates of $\mathrm{N}$ fertilizers $\left(0,50,100,150\right.$ and $\left.300 \mathrm{~kg} \mathrm{ha}^{-1}\right)$ and maize crop rotation with soybean and monoculture maize was tested on P uptake and AMF communities in the soil were tested. In maize roots, the biomass of AMF was increased from one stage to another but it was not affected by $\mathrm{N}$ fertilizers or rotation with soybean. The detection of AMF provided indirect evidence of $\mathrm{P}$ uptake by AMF in maize roots derived acid, alkaline and polyphosphates. The $\mathrm{N}$ fertilization did not affect the AMF associated $\mathrm{P}$ uptake, but its maximum value was recorded in the monoculture maize. The spores frequency of AMF is varied with different levels of $\mathrm{N}$ fertilizers which is an important aspect for agroecosystem management [94].

Furthermore, AMF can change plant physiology and the microbial populations in the soil due to specific features of mycorrhized rhizosphere than non-mycorrhized rhizosphere. In the soil, AMF are involved in all fundamental activities necessary for a healthy natural and agricultural ecosystem. There are various agents 
such as overdosing of commercial fertilizers, faulty cultivation practices, fungicides and use of nonmycorrhizal plants that affect the performance and efficiency of AMF in spore formation and colonization as well as sustainable crop production [95]. Pellegrino et al. [96] explored the influence of two mycorrhiza inocula (native and exotic) in T. alexandrium and maize crop rotation. They studied the effect of four exotic AM fungal isolates on physiological traits of Trifolium alexandrium in green-house conditions. Trifolium alexandrium was inoculated with single and mixed inoculums of exotic AMF and the results were compared with those of native inoculums.

Furthermore, the residual effect of AMF inoculation under field conditions was assessed on the subsequent maize crops. Analysis of the data indicated that the field inoculation with the AMF inoculum increased the quality and productivity of T. alexandrium and maize crops. Moreover, the native AMF inoculum was more effective as than the exotic AMF inocula. It was also observed that the beneficial effects of AMF were consistent until the second year of crop growth. Thus, the application and use of native AMF inocula are economically and ecologically an important alternative approach compared to commercial AM inocula for sustainable agricultural systems.

Arbuscular mycorrhiza fungi play a key role in soil aggregation [97]. AMF affects the shoot to root ratio, plant physiology, nutrients uptake by plants and highly affect soil aggregates formation during symbiosis. When AMF affect the plant root system, the AMF increases the potential of plants roots and root hairs to bind soil particles [97]. Hallett et al. [98] reported that plants roots apply stress on soil particles and bind these soil particles to facilitate the formation of soil aggregates. In addition to this, AMF affects the pressure of plant roots by their branching pattern [97]. Arbuscular mycorrhiza fungi are also involved in certain biochemical and biological processes necessary for soil aggregate formation. Just like plants, the AMF hyphae bind the microparticles of soil into macroparticles. AMF produces some glomalin-related protein and mucilage's that help soil aggregate formation in the soil and plant rhizosphere. These proteins increase the coating of these particles and enhance their stability [99] and preventing them from dispersing and disintegrating (Fig. 3).

\subsection{Mechanisms and Role of PSB in the Phosphorus Solubility to Crops}

The PSB have been used for increasing crop growth and productivity for decades [73]. In soils, there are many different bacterial species capable of solubilizing insoluble P to its soluble form, and are called PSB. These bacteria increase plant growth and colonize plant roots; therefore, they are also called PGPR [86]. The PSB supply P to plants in a sustainable and environment friendly manner. Plant provides areas, energy, shelter, food and areas of biological diversity to PSB. There are various modes of actions by which PSB solubilize $\mathrm{P}$ and give it to plants by producing phenolic compounds [100], organic acids [45], siderophore and hormones secretion [63]. Ivanova et al. [101] reported that in the soil different bacterial species have the potential to increase the RP solubility of soil-bound $\mathrm{P}$ in soil as well as in culture medium by secreting organic acids. These acids destroy the $\mathrm{P}$ bound structures and thus make $\mathrm{P}$ soluble for the uptake of plants [35]. In soil the efficient PSB strains increase the bioavailability of $P$ and thus the overall plant growth is improved. The PSB have the ability to increase the growth of cereals, legumes, fiber crops, horticulture crops and oil seed crops [35].

The ability of PSB strains like Pantoea cypripedii and Pseudomonas plecoglossicida have been documented to enhance maize and wheat total dry biomasses, grain yield and fertility of soil. Furthermore, $\mathrm{P}$ uptake, available soil $\mathrm{P}$ and PSB populations are also significantly increased by PSB inoculation with RP. A significant increase in crop yield and soil fertility are very obvious due to PSB inoculation with RP compared to controls. Moreover, inoculation of PSB P. cypripedii (PSB-3) and $P$. plecoglossicida (PSB-5) with RP can enhance the growth and fertility of soil [102]. The PSB strains can improve the growth of maize, $\mathrm{P}$ solubility and production of plant growth-promoting substances. PSB inoculation also enhances the concentration of $\mathrm{P}$ in roots, shoots and maize biomass in treatments without 
P fertilizers. The soils fertilized with tricalcium $\mathrm{P}$ also enhance plant biomass due to the inoculation of PSB and $\mathrm{P}$ in the tissues. The increase in plant growth is not only due to $\mathrm{P}$ solubilization but also to some other plant growth-promoting traits. It is clear that the PSB strains may be efficiently used as a biofertilizer in P deficient soils to increase P solubility and maize productivity [103]. Kaur et al. [102] conducted 2-year experiment in the field to explore the efficiency of two efficient PSB strains with and without RP on maize and wheat cropping systems. They recorded that the inoculation of PSB with RP increased shoot and root dry biomasses, grain yield, plant height and plant $\mathrm{P}$ uptake on both wheat and maize compared to control and other treatments. The combined use of PSB with RP was more economical due to its low cost and more returns. da Costa et al. [5] conducted an experiment on an oxisol to evaluate the effect of inoculated PSB on rice plants fertilized with RP on growth and nutrient accumulation. All of the inoculated PSB strains enhanced shoot, root and total dry matters, and $\mathrm{P}, \mathrm{N}, \mathrm{Ca}, \mathrm{Mg}, \mathrm{S}$ and $\mathrm{B}$ concentrations compared with the treatment without PSB. They also noted that the increase shoot and root dry biomasses was $52 \%$ and $120 \%$, respectively, due to the inoculation with Paenibacillus kribbensis. This study also indicates that the inoculation of rice plants with PSB amended with RP is a suitable and economical approach to enhance growth and P uptake by plants of this species.

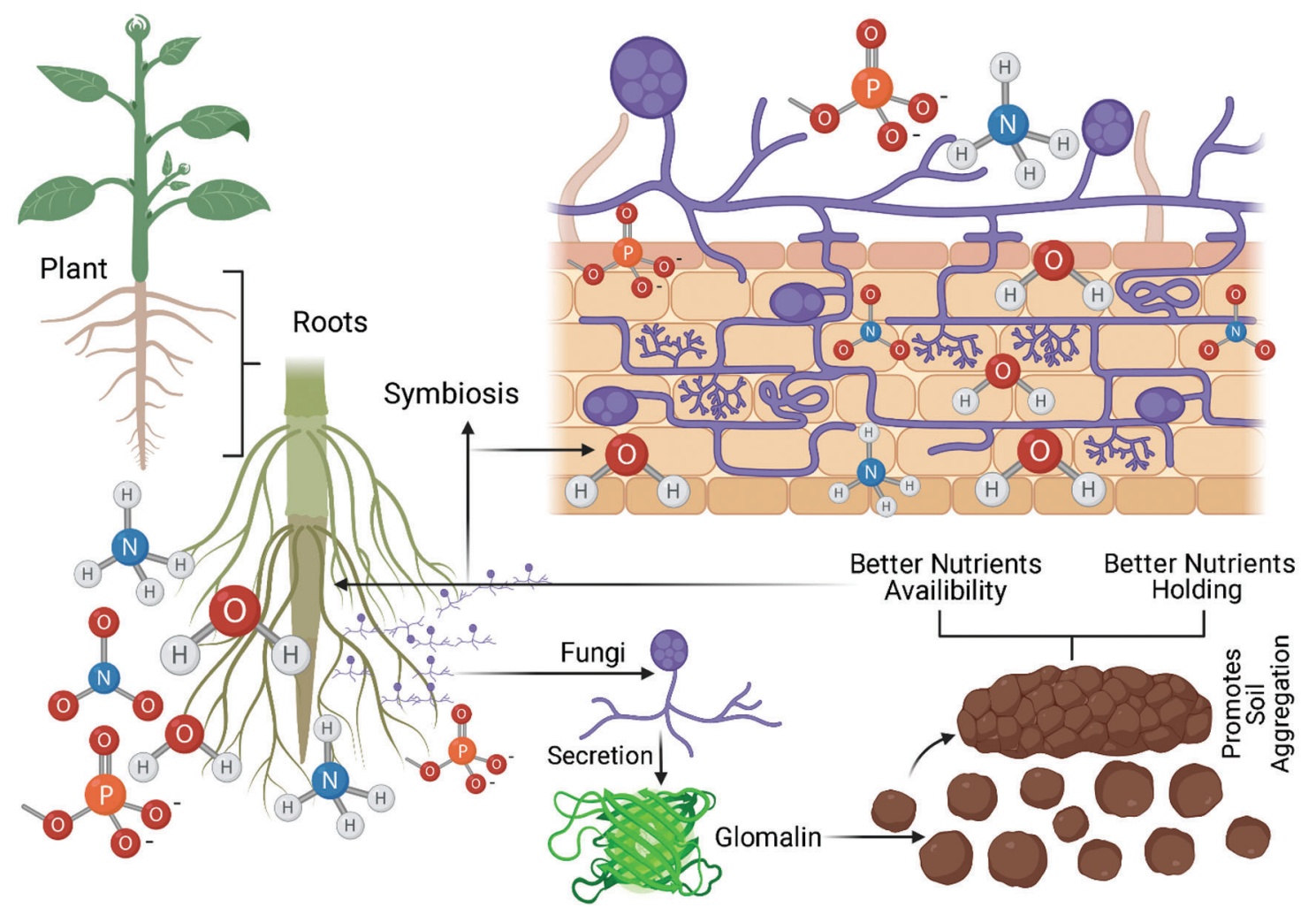

Figure 3: Regulation of nutrients and water by arbuscular mycorrhizal fungi (AMF)

\subsection{Phosphate Solubilizing Bacteria as a Biocontrol Agent}

Phosphate solubilizing bacteria and plant growth-promoting bacteria are important to soil ecology and as a biocontrol agent. They are abundant in the soil and the plant rhizosphere. In the soil they perform different functions and can be widely used to suppress the activity of different bacteria, fungi and nematodes spreading diseases [104,105]. Furthermore, PSB are also widely used as biofertilizer in many agricultural soils instead of commercial P fertilizers [76]. Moreover, PGPR are also very important for the control of plant pathogens 
in soils [104]. It has been found that Pseudomonas sp. acts as an important biocontrol agent in the plant rhizosphere [105]. These bacteria secret several metabolites, gluconic acid, siderophores, and enzymes which help in controlling diseases and thus act as a biocontrol agent [106]. Pseudomonas and PSB are specialized characteristics that make them plant growth promoting rhizobacteria [107].

The specialized characters of PSB are that they rapidly colonize, rapidly use root exudates, produce biocontrol metabolites and rapidly colonize in soils. Another important species of PSB which act as a biocontrol agent is Bacillus subtilis. This bacteria specie has the ability to release endospores and some active compounds in soil for various functions [108]. Bacillus megaterium is also used to enhance $\mathrm{P}$ and release of antifungal metabolites, siderophores and indole acetic acid, thus reducing the intensity of diseases on plants [109]. Phosphate solubilizing bacteria are also used in integrated pest management in agriculture.

\subsection{Interactive Mechanisms and Role of AMF and PSB in Phosphorus Availability to Crops}

The AMF interactions with PSB in increasing P solubility, availability and uptake by the plants have been documented since 1990 [110]. Both the organic and inorganic P forms are unavailable to plants due to their chemical bonding with clay surfaces and fixation with other soil nutrients and crystal lattices. In the rhizosphere soil there are many PSBs that can improve the availability of organic and inorganic $\mathrm{P}$ to plants (Tab. 3) with the help of AM species $[76,111]$. These bacteria produce some organic acids, which help in the solubility of both organic and inorganic forms of $\mathrm{P}$, and subsequently provide it to the plants with the help of AM hyphae [12,35,83]. In P deficient soils, plant inoculation with AMF and PSB not only increase P uptake but also enhance the phosphatase activity [112], PSB number [113] and mycorrhization [114]. Artursson et al. [115] reported that there are different strains of bacteria such as Pseudomonas, Bacillus, Paenibacillus and Rhizobia which have positive association with several types of AM species including Glomus mosseae, G. calrum, G. versiforme and G. intraradices in the soil [114,115]. The combined inoculation of these microbes resulted in AMF growth, spores formation, colonization of the host plant, P solubility and pathogen suppression [115].

Table 3: Residual effect of AMF and PSB with RP on soil $\mathrm{P}$ concentration in post harvest wheat crop

\begin{tabular}{llll}
\hline Treatments & $\begin{array}{l}\text { Grain yield } \\
\left(\mathrm{kg} \mathrm{ha}^{-1}\right)\end{array}$ & $\begin{array}{l}\text { Plant } \mathrm{P} \text { uptake } \\
\left(\mathrm{kg} \mathrm{ha}^{-1}\right)\end{array}$ & $\begin{array}{l}\text { Soil P concentration } \\
\left(\mathrm{mg} \mathrm{kg}^{-1}\right)\end{array}$ \\
\hline Control (No fertilizers) & $1720 \pm 12 \mathrm{~h} *$ & $2.04 \pm 0.71 \mathrm{~h} *$ & $1.11 \pm 0.21 \mathrm{~g}^{*}$ \\
N \& K fertilizers & $1981 \pm 13 \mathrm{~g}$ & $4.64 \pm 0.96 \mathrm{gh}$ & $1.25 \pm 0.22 \mathrm{~g}$ \\
SSP & $2292 \pm 84 \mathrm{ef}$ & $10.02 \pm 1.3 \mathrm{ef}$ & $3.75 \pm 0.39 \mathrm{ef}$ \\
RP & $2555 \pm 67 \mathrm{~d}$ & $13.58 \pm 1.5 \mathrm{~cd}$ & $4.29 \pm 0.49 \mathrm{e}$ \\
Bacillus sp. & $2420 \pm 38 \mathrm{de}$ & $10.48 \pm 0.97 \mathrm{de}$ & $5.55 \pm 1.71 \mathrm{~d}$ \\
AMF & $2150 \pm 17 \mathrm{fg}$ & $7.13 \pm 0.76 \mathrm{fg}$ & $3.10 \pm 0.31 \mathrm{f}$ \\
AMF+Bacillus sp. & $3061 \pm 14 \mathrm{~b}$ & $20.98 \pm 3.75 \mathrm{~b}$ & $5.99 \pm 0.22 \mathrm{~cd}$ \\
RP+Bacillus sp. & $3316 \pm 27 \mathrm{a}$ & $18.79 \pm 3.5 \mathrm{~b}$ & $7.40 \pm 0.22 \mathrm{ab}$ \\
RP+AMF & $2770 \pm 83 \mathrm{c}$ & $15.36 \pm 2.0 \mathrm{c}$ & $6.70 \pm 0.37 \mathrm{bc}$ \\
RP+AMF+Bacillus sp. & $3101 \pm 18 \mathrm{~b}$ & $24.49 \pm 5.4 \mathrm{a}$ & $8.05 \pm 0.17 \mathrm{a}$ \\
LSD $($ P $\leq 0.01)$ & 179 & 3.2 & 1.11 \\
\hline
\end{tabular}

Source: Wahid et al. [76]. ${ }^{*}$ Different letters showed significant difference at $\mathrm{p}<0.05$. 
Several pot culture studies have been conducted regarding the combined application of AMF and PSB in the rhizosphere [80,116]. Some of their results indicate that the direct interaction between AMF and PSB was not significant because the Glomus intraradices lacks the phytase protein which is important for the utilization of phytate in the soil. Moreover, AMF also influences the potential bacteria directly and indirectly in the plant rhizosphere [117]. Additionally, PSB interrelate with AMF due to their capability to colonize roots in the presence of spores and surfaces of AM hyphae [118], and thus affect the root infection intensity, hyphal growth [119] and the availability of nutrients for the capturing of AM hyphae [120,121]. The interaction between AMF and PSB also enhance N and P uptake by plants [115].

Furthermore, the co-inoculation of AMF and PSB also improves RP mineralization and P uptake (Tab. 3) [112,122], and thus plays an important role in developing P fertilizers. Toro et al. [123] studied the synergistic effects of AMF and PSB in P deficient soils; they concluded that the treatments having both AMF and PSB significantly increased plant dry biomass (Tab. 4), and nutrient concentration in plant tissues. Moreover, they also observed the beneficial effects of PSB on AMF establishment, and the increasing population of PSB by AMF in the plant rhizosphere.

Table 4: Shoot and root dry matter yields and plants height of maize as influenced by the inoculation of AMF and PSB with RP

\begin{tabular}{llll}
\hline Treatments & $\begin{array}{l}\text { Dry shoot } \\
\text { biomass }\left(\mathrm{g} \mathrm{pot}^{-1}\right)\end{array}$ & $\begin{array}{l}\text { Dry root } \\
\text { biomass }\left(\mathrm{g} \mathrm{pot}^{-1}\right)\end{array}$ & Plant height (cm) \\
\hline Control (N and K) & $25.70 \mathrm{~g}^{*}$ & $8.33 \mathrm{~g}^{*}$ & $69.70 \mathrm{~h} *$ \\
Single Super phosphate (SSP) & $56.33 \mathrm{a}$ & $17.33 \mathrm{a}$ & $106.20 \mathrm{abs}$ \\
Rock Phosphate (RP) & $37.00 \mathrm{f}$ & $11.70 \mathrm{f}$ & $74.00 \mathrm{gh}$ \\
Streptococcus & $39.00 \mathrm{ef}$ & $13.00 \mathrm{def}$ & $78.00 \mathrm{fgh}$ \\
Bacillus & $42.00 \mathrm{def}$ & $13.70 \mathrm{cdef}$ & $84.00 \mathrm{efg}$ \\
Coccus & $41.33 \mathrm{def}$ & $13.33 \mathrm{cdef}$ & $81.00 \mathrm{fgh}$ \\
Arbuscular Mycorrhiza Fungi (AMF) & $37.33 \mathrm{f}$ & $12.00 \mathrm{ef}$ & $76.00 \mathrm{gh}$ \\
RP + Streptococcus & $45.70 \mathrm{cde}$ & $15.33 \mathrm{abcd}$ & $100.33 \mathrm{bc}$ \\
RP + Bacillus & $53.00 \mathrm{abc}$ & $15.70 \mathrm{abc}$ & $98.70 \mathrm{bcd}$ \\
RP + Coccus & $52.33 \mathrm{abc}$ & $16.33 \mathrm{ab}$ & $95.70 \mathrm{bcde}$ \\
RP + AMF & $48.00 \mathrm{bcd}$ & $14.33 \mathrm{bcde}$ & $90.70 \mathrm{cdef}$ \\
RP + AMF + Streptococcus & $58.00 \mathrm{a}$ & $16.70 \mathrm{ab}$ & $108.6 \mathrm{ab}$ \\
RP + AMF + Bacillus & $54.70 \mathrm{ab}$ & $15.70 \mathrm{abc}$ & $107.00 \mathrm{ab}$ \\
RP + AMF + Coccus & $53.70 \mathrm{ab}$ & $16.70 \mathrm{ab}$ & $118.67 \mathrm{a}$ \\
LSD (P $\leq 0.05)$ & 7.43 & 2.40 & 13.90 \\
\hline
\end{tabular}

Source: Wahid et al. [35]. *Different letters showed significant difference at $\mathrm{p}<0.05$.

Several researchers have also reported the synergistic effect between AM fungi and plant growthpromoting rhizobacteria (PGPR) in the soil. These bacteria enhance plant growth and development by interacting with AM fungi (Tab. 4), controlling pathogens, increasing nutrient solubility, and releasing plant hormones $[122,124]$. PGPR can increase nutrients uptake and development of AMF by affecting plant root colonization [55]. Bianciotto et al. [125] reported that Azospirillum and Rhizobium produce extracellular polysaccharides that improve bacterial strain's attachment ability with AMF structures and 
plant roots. Kim et al. [126] suggested that co-inoculation of AMF and Methylobacterium oryzae is useful for plant growth, macro and micronutrients, chlorophyll content and root colonization. Artursson et al. [115] found that the binding strength of bacteria with the AM hyphae varies in different physiological stages of attachment. This is because, it is weak at the first stage and then became strong in the second stage. The possible reason for this might be the presence of some extracellular products or cellulose produced by the bacteria.

Moreover, the attachment of Gram+ve bacteria is more effective than G-ve bacteria with AMF [127]. Most PGPR, such as Bacillus sp. (Gram+ve) show positive interaction with AMF. Hameeda et al. [128] found certain plant growth-promoting bacteria, including fluorescent pseudomonads, nitrogen fixers and sporulating bacilli in soil, having a synergistic effect with AM fungi. Meyer et al. [129] found an increase in root colonization of subterranean clover by the combined application of PGPR with AMF.

The synergistic effects of PSB (Bacillus megaterium) and two AMF strains on maize growth in the presence of tribasic calcium phosphate positively affect maize colonization. The PSB population and maize biomass were found high only with the GA8 strain. The increase in PSB density might be due to the transfer of some photosynthates in the maize rhizosphere [130]. Rhizobium and AM fungi interaction increase the solubilization of rock phosphate in $\mathrm{P}$ deficient soils and consequently enhance the growth and yield of burgundy plants (Macroptilum bracteatum) under pot conditions [131]. The combined inoculation effect of two local phosphate solubilizing bacteria strains (Pseudomonas fluorescens BAM4 and Burkholderia cepacia BAM12) and AMF (Glomus etunicatum) on different growth parameters (dry shoot yield, root yield and leaf area) and nutrient uptake of wheat crop fertilized with tricalcium phosphate in $\mathrm{P}$ deficient soil significantly enhance the growth parameters and nutrient contents of wheat plants [132].

Similarly, the synergistic role of plant growth promoting rhizobacteria (PGPRs) such as Pseudomonas putida, Azotobacter chroococcum and Bacillus polymixa in combination with Glomus intradices increase root dry weight, shoot dry weight, nutrient contents (NPK), chlorophyll and stevioside (i.e., a glycoside) in plants under greenhouse conditions. The interactions of AMF (Funneliformis mosseae) and earthworms (Eisenia petidia) in the presence of insoluble phytate $\mathrm{P}$ enhance dry shoot and root biomass, $\mathrm{P}$ uptake, alkaline soil phosphates activities, microbial biomass $\mathrm{P}$ and soil available P. Moreover, the synergistic effects between these microbes also improve the phosphate activities and microbial biomass $\mathrm{P}$ and regulate the bacteria populations in soil [133]. Furthermore, the PSB strains (Bacillus sp. RM2 and Aspergillus niger S36) isolated from rhizosphere soil of Sesamum indicum and Vigna radiate significantly enhance chickpea growth as compared to single inoculation and control treatment, and can be used in the preparation of biofertilizers for sustainable agriculture [134].

\section{Future Prospects}

The use of beneficial microorganisms such as arbuscular mycorrhizal fungi (AMF) and phosphate solubilizing bacteria (PSB) is an environmentally friendly approach for increasing nutrient solubility and agricultural sustainability. The use of these microorganisms as biofertilizers is of paramount importance in the fields of food safety and sustainable crop production. For this reason, biological fertilizers, which are useful in solubilization of hardly available phosphate sources and meet the nutritional requirements of plants without undesirable effects on the environment and human health, should be ensured in future research. In addition, the biofertilizers play an essential role in lowering fertilizer and pesticide costs. Current developments in our understanding regarding the mode of action, roots colonizing ability, and proper application are likely to facilitate their use as reliable components in managing sustainable agricultural systems. Furthermore, scientists need to address certain issues, like how to improve the efficacy of biofertilizers, what should be an ideal and universal delivery system, how to stabilize these microbes in soil systems, and how nutritional and root exudation aspects could be controlled to obtain 
maximum benefits from beneficial microbe's application. Biotechnological and molecular approaches could be adopted to increase our understanding about the microbial mode of actions for P solubility, that could lead to more successful plant-microbe interactions in sustainable crop production systems.

\section{Conclusion}

It is concluded that the phosphorus solubility from both organic and inorganic sources in the soil may be enhanced by the combined inoculation of AMF and PSB, and thus it is a promising approach for sustainable management of $\mathrm{P}$ in agriculture. Hence, the use of AMF and PSB strains as biofertilizers is an imperative strategy for reducing the potential risk of high-cost $\mathrm{P}$ fertilizers and may be utilized effectively for increasing crop production in $\mathrm{P}$ deficient soils. Moreover, mass inoculum production of different indigenous species of AMF and PSB for field crops production is urgently needed under different agro ecological conditions.

Acknowledgement: We are thankful to Pakistan Journal of Botany who permit us for the use of data tabs 2-4.

Funding Statement: The authors received no specific funding for this study.

Conflicts of Interest: The authors declare that they have no conflicts of interest to report regarding the present study.

\section{References}

1. Naseer, M., Muhammad, D. (2014). Direct and residual effect of hazara rock phosphate (HRP) on wheat and succeeding maize in alkaline calcareous soils. Pakistan Journal of Botany, 46(5), 1755-1761.

2. Cozzolino, V., di Meo, V., Piccolo, A. (2013). Impact of arbuscular mycorrhizal fungi applications on maize production and soil phosphorus availability. Journal of Geochemical Exploration, 129, 40-44. DOI 10.1016/j. gexplo.2013.02.006.

3. Khan, M. S., Zaidi, A., Ahemad, M., Oves, M., Wani, P. A. (2010). Plant growth promotion by phosphate solubilizing fungi-current perspective. Archives of Agronomy and Soil Science, 56(1), 73-98. DOI 10.1080/ 03650340902806469 .

4. Collavino, M. M., Sansberro, P. A., Mroginski, L. A., Aguilar, O. M. (2010). Comparison of in vitro solubilization activity of diverse phosphate-solubilizing bacteria native to acid soil and their ability to promote phaseolus vulgaris growth. Biology and Fertility of Soils, 46, 727-738. DOI 10.1007/s00374-010-0480-x.

5. Martins da Costa, E., de Lima, W., Oliveira-Longatti, S. M., de Souza, F. M. (2015). Phosphate-solubilising bacteria enhance Oryza sativa growth and nutrient accumulation in an oxisol fertilized with rock phosphate. Ecological Engineering, 83, 380-385. DOI 10.1016/j.ecoleng.2015.06.045.

6. Rai, P. K., Lee, S. S., Zhang, M., Tsang, Y. F., Kim, K. H. (2019). Heavy metals in food crops: Health risks, fate, mechanisms, and management. Environment International, 125, 365-385. DOI 10.1016/j.envint.2019.01.067.

7. Mttra, S., Roy, A., Saha, A. R., Maitra, D. N., Sinha, M. K. et al. (2010). Effect of integrated nutrient management on fibre yield, nutrient uptake and soil fertility in jute (Corchorus olitorius). Indian Journal of Agricultural Sciences, 80(9), 801-804.

8. Tilman, D., Cassman, K. G., Matson, P. A., Naylor, R., Polasky, S. (2002). Agricultural sustainability and intensive production practices. Nature, 418(6898), 671-677. DOI 10.1038/nature01014.

9. Abd El-Malek, A. A. (2005). Biofertilization usage of producing environmentally safe potato crop. Cairo, Egypt: Faculty of Agriculture Ain Shams University.

10. Abou El-Yazied, A. M., Sellim, A. S. M. (2007). Effect of reducing N, P mineral fertilization levels combined with Bio fertilizer on growth, yield and tuber quality of potato plants. Journal of Agricultural Sciences, 32, 2701-2726.

11. Yadav, A., Ashok, A. (2014). Effect of dual inoculation of AM fungi and pseudomonas with phosphorus fertilizer rates on growth performance, nutrient uptake and yield of soybean. Researcher, 6(11), 5-13. 
12. Danish, S., Younis, U., Akhtar, N., Ameer, A., Ijaz, M. et al. (2015). Phosphorus solubilizing bacteria and rice straw biochar consequence on maize pigments synthesis. International Journal of Biosciences, 5(12), 31-39. DOI 10.12692/ijb/5.12.31-39.

13. Zafar-ul-Hye, M., Shahjahan, A., Danish, S., Abid, M., Qayyum, M. F. (2018). Mitigation of cadmium toxicity induced stress in wheat by ACC-deaminase containing PGPR isolated from cadmium polluted wheat rhizosphere. Pakistan Journal of Botany, 50(5), 1727-1734. http://www.pakbs.org/pjbot/papers/1527614711.pdf.

14. Danish, S., Zafar-ul-Hye, M., Hussain, S., Riaz, M., Qayyum, M. F. (2020). Mitigation of drought stress in maize through inoculation with drought tolerant ACC deaminase containing PGPR under axenic conditions. Pakistan Journal of Botany, 52(1), 49-60.

15. Ahmed, N., Ahsen, S., Ali, M. A., Hussain, M. B., Hussain, S. B. et al. (2020). Rhizobacteria and silicon synergy modulates the growth, nutrition and yield of mungbean under saline soil. Pakistan Journal of Botany, 52(1), 915. DOI 10.30848/PJB2020-1(16).

16. Danish, S., Kiran, S., Fahad, S., Ahmad, N., Ali, M. A., et al. (2019). Alleviation of chromium toxicity in maize by $\mathrm{Fe}$ fortification and chromium tolerant ACC deaminase producing plant growth promoting rhizobacteria. Ecotoxicology and Environmental Safety, 185, 109706. DOI 10.1016/j.ecoenv.2019.109706.

17. Danish, S., Zafar-ul-Hye, M., Fahad, S., Saud, S., Brtnicky, M. et al. (2020). Drought stress alleviation by ACC deaminase producing achromobacter xylosoxidans and enterobacter cloacae, with and without timber waste biochar in maize. Sustainability, 12(15), 6286. DOI 10.3390/SU12156286.

18. Pierre, M. J., Sopan Bhople, D. B., Kumar, D. A., Erneste, H., Emmanuel, B. et al. (2014). Contribution of arbuscular mycorrhizal fungi (AM fungi) and rhizobium inoculation on crop growth and chemical properties of rhizospheric soils in high plants. IOSR Journal of Agriculture and Veterinary Science, 7, 45-55. DOI 10.9790/2380-07944555.

19. van der Heijden, M. G. A., Bardgett, R. D., van Straalen, N. M. (2008). The unseen majority: Soil microbes as drivers of plant diversity and productivity in terrestrial ecosystems. Ecology Letters, 11(3), 296-310. DOI 10.1111/j.1461-0248.2007.01139.x.

20. Nair, D. N., Padmavathy, S. (2014). Impact of endophytic microorganisms on plants, environment and humans. The Scientific World Journal, 2014, 1-11. DOI 10.1155/2014/250693.

21. Khan, M. S., Zaidi, A., Wani, P. A. (2007). Role of phosphate-solubilizing microorganisms in sustainable agriculture-A review. Agronomy for Sustainable Development, 27(1), 29-43. DOI 10.1051/agro:2006011.

22. McMillan, S. (2007). Promoting growth with PGPR. The canadian organic grower, pp. 3-4. Soil Foodweb Canada Ltd. Soil Biology Lab. \& Learning Centre, 2007.

23. Rodríguez, H., Fraga, R., Gonzalez, T., Bashan, Y. (2006). Genetics of phosphate solubilization and its potential applications for improving plant growth-promoting bacteria. Plant and Soil, 287(1-2), 15-21. DOI 10.1007/ s11104-006-9056-9.

24. Burd, G. I., Dixon, D. G., Glick, B. R. (2000). Plant growth-promoting bacteria that decrease heavy metal toxicity in plants. Canadian Journal of Microbiology, 46, 237-245. DOI 10.1139/w99-143.

25. Smith, S. E., Read, D. (2008). Growth and carbon economy of arbuscular mycorrhizal symbionts. In: S. E. Smith, D. Read (Eds.), Mycorrhizal symbiosis, 3rd ed., pp. 117-144. Academic Press Inc., Elsevier. London, UK. DOI 10.1016/b978-012370526-6.50006-4.

26. Schüßler, A., Schwarzott, D., Walker, C. (2001). A new fungal phylum, the glomeromycota: Phylogeny and evolution. Mycological Research, 105(12), 1413-1421. DOI 10.1017/s0953756201005196.

27. Sosa-Hernández, M. A., Leifheit, E. F., Ingraffia, R., Rillig, M. C. (2019). Subsoil arbuscular mycorrhizal fungi for sustainability and climate-smart agriculture: A solution right under our feet? Frontiers in Microbiology, 10, 744. DOI 10.3389/fmicb.2019.00744.

28. Pozo, M. J., Azcón-Aguilar, C. (2007). Unraveling mycorrhiza-induced resistance. Current Opinion in Plant Biology, 10(4), 393-398. DOI 10.1016/j.pbi.2007.05.004.

29. Begum, N., Qin, C., Ahanger, M. A., Raza, S., Khan, M. I. et al. (2019). Role of arbuscular mycorrhizal fungi in plant growth regulation: Implications in abiotic stress tolerance. Frontiers in Plant Science, 10, 1068. DOI 10.3389/fpls.2019.01068. 
30. Cavagnaro, T. R., Jackson, L. E., Six, J., Ferris, H., Goyal, S. et al. (2006). Arbuscular mycorrhizas, microbial communities, nutrient availability, and soil aggregates in organic tomato production. Plant and Soil, 282(1-2), 209-225. DOI 10.1007/s11104-005-5847-7.

31. Chen, X., Tang, J., Zhi, G., Hu, S. (2005). Arbuscular mycorrhizal colonization and phosphorus acquisition of plants: Effects of coexisting plant species. Applied Soil Ecology, 28(3), 259-269. DOI 10.1016/j. apsoil.2004.07.009.

32. Sumana, D. A., Bagyaraj, D. J., Arpana, J. (2003). Interaction between Glomus mosseae, Azotobacter chroococcum and Bacillus coagulans and their influence on growth and nutrition of neem. Journal of Soil Biology Ecology, 23, 80-86.

33. Chen, Y. P., Rekha, P. D., Arun, A. B., Shen, F. T., Lai, W. A. et al. (2006). Phosphate solubilizing bacteria from subtropical soil and their tricalcium phosphate solubilizing abilities. Applied Soil Ecology, 34(1), 33-41. DOI 10.1016/j.apsoil.2005.12.002.

34. Zhang, H., Wu, X., Li, G., Qin, P. (2011). Interactions between arbuscular mycorrhizal fungi and phosphatesolubilizing fungus (Mortierella sp.) and their effects on kostelelzkya virginica growth and enzyme activities of rhizosphere and bulk soils at different salinities. Biology and Fertility of Soils, 47(5), 543-554. DOI 10.1007/s00374-011-0563-3.

35. Wahid, F., Sharif, M., Steinkellner, S., Khan, M. A., Marwat, K. B. et al. (2016). Inoculation of arbuscular mycorrhizal fungi and phosphate solubilizing bacteria in the presence of rock phosphate improves phosphorus uptake and growth of maize. Pakistan Journal of Botany, 48(2), 739-747.

36. Ordoñez, Y. M., Fernandez, B. R., Lara, L. S., Rodriguez, A., Uribe-Vélez, D. et al. (2016). Bacteria with phosphate solubilizing capacity alter mycorrhizal fungal growth both inside and outside the root and in the presence of native microbial communities. PLoS One, 11, 0154438. DOI 10.1371/journal.pone.0154438.

37. Balemi, T., Negisho, K. (2012). Management of soil phosphorus and plant adaptation mechanisms to phosphorus stress for sustainable crop production: A review. Journal of Soil Science and Plant Nutrition, 12(3), 547-562. DOI 10.4067/s0718-95162012005000015.

38. Cordell, D., Rosemarin, A., Schröder, J. J., Smit, A. L. (2011). Towards global phosphorus security: A systems framework for phosphorus recovery and reuse options. Chemosphere, 84(6), 747-758. DOI 10.1016/j. chemosphere.2011.02.032.

39. Hellal, F., El-Sayed, S., Zewainy, R., Amer, A. (2019). Importance of phosphate pock application for sustaining agricultural production in Egypt. Bulletin of the National Research Centre, 43(1), 1-11. DOI 10.1186/s42269019-0050-9.

40. Cicek, H., Bhullar, G. S., Mandloi, L. S., Andres, C., Riar, A. S. (2020). Partial acidulation of rock phosphate for increased productivity in organic and smallholder farming. Sustainability, 12(2), 607. DOI 10.3390/su12020607.

41. Sharma, S. B., Sayyed, R. Z., Trivedi, M. H., Gobi, T. A. (2013). Phosphate solubilizing microbes: Sustainable approach for managing phosphorus deficiency in agricultural soils. SpringerPlus, 2, 587. DOI 10.1186/21931801-2-587.

42. Vance, C. P., Uhde-Stone, C., Allan, D. L. (2003). Phosphorus acquisition and use: Critical adaptations by plants for securing a nonrenewable resource. New Phytologist, 157(3), 423-447. DOI 10.1046/j.14698137.2003.00695.x.

43. Soltan, S., Römer, W., Adgo, E., Gerke, J., Schilling, G. (1993). Phosphate sorption by Egyptian. Ethiopian and German soils and P uptake by rye (Secale cereale L.) seedlings. Zeitschrift Für Pflanzenernährung Und Bodenkunde, 156(6), 501-506. DOI 10.1002/jpln.19931560608.

44. Vance, C. P. (2001). Symbiotic nitrogen fixation and phosphorus acquisition. plant nutrition in a world of declining renewable resources. Plant Physiology, 127(2), 390-397. DOI 10.1104/pp.127.2.390.

45. Goldstein, A. H. (1995). Recent progress in understanding the molecular genetics and biochemistry of calcium phosphate solubilization by gram negative bacteria. Biological Agriculture and Horticulture, 12(2), $185-193$. DOI 10.1080/01448765.1995.9754736. 
46. Fink, J. R., Inda, A. V., Bavaresco, J., Sánchez-Rodríguez, A. R., Barrón, V. et al. (2016). Diffusion and uptake of phosphorus, and root development of corn seedlings, in three contrasting subtropical soils under conventional tillage or no-tillage. Biology and Fertility of Soils, 52(2), 203-210. DOI 10.1007/s00374-015-1067-3.

47. Syers, J. K., Johnston, A. E., Curtin, D. (2009). Efficiency of soil and fertilizer phosphorus: Reconciling changing concepts of soil phosphorus behaviour with agronomic information. FAO Fertilizer and Plant Nutrition Bulletin, 18, 108. DOI 10.1017/s0014479708007138.

48. Turner, B. L., McKelvie, I. D., Haygarth, P. M. (2002). Characterisation of water-extractable soil organic phosphorus by phosphatase hydrolysis. Soil Biology and Biochemistry, 34(1), 27-35. DOI 10.1016/s00380717(01)00144-4.

49. Richardson, A. E. (2001). Prospects for using soil microorganisms to improve the acquisition of phosphorus by plants. Australian Journal of Plant Physiology, 28, 897-906. DOI 10.1071/PP01093.

50. Goldstein, A. H. (1986). Bacterial solubilization of mineral phosphates: Historical perspective and future prospects. American Journal of Alternative Agriculture, 1(2), 51-57. DOI 10.1017/S0889189300000886.

51. Saha, N., Biswas, S. (2009). Mineral phosphate solubilizing bacterial community in agro-ecosystem. African Journal of Biotechnology, 8(24), 6863-6870. DOI 10.4314/ajb.v8i24.68765.

52. Eftekhari, G., Fallah, A. R., Akbari, G. A., Mohaddesi, A., Allahdadi, I. (2010). Effect of phosphate solubilising bacteria and phosphate fertilizer on rice growth parameters. Iranian Journal of Soil Research (Formerly Soil and Water Sciences), 23(2), 229-238.

53. Bieleski, R. L. (1973). Phosphate pools, phosphate transport, and phosphate availability. Annual Review of Plant Physiology, 24(1), 225-252. DOI 10.1146/annurev.pp.24.060173.001301.

54. Tinker, P. B., Nye, P. (2000). Solute transport in the soil near root surfaces. In: P. B. Tinker, P. Nye (Eds.), Solute movement in the Rhizosphere (2nd ed.). New York, USA: Oxford University Press. DOI 10.1093/oso/ 9780195124927.003.0010.

55. Richardson, A. E., Barea, J. M., McNeill, A. M., Prigent-Combaret, C. (2009). Acquisition of phosphorus and nitrogen in the rhizosphere and plant growth promotion by microorganisms. Plant and Soil, 321(1-2), 305339. DOI 10.1007/s11104-009-9895-2.

56. Rashid, A., Ryan, J. (2006). Phosphorus. In: Lal, R. (Ed.), Encyclopedia of soil science, 2nd ed., pp. 1275-1279. New York, London: Taylor \& Francis Group. DOI 10.1201/2Fnoe0849338304.ch267.

57. Shrivastava, M., Kale, S. P., D’Souza, S. F. (2011). Rock phosphate enriched post-methanation bio-sludge from kitchen waste based biogas plant as P source for mungbean and its effect on rhizosphere phosphatase activity. European Journal of Soil Biology, 47(3), 205-212. DOI 10.1016/j.ejsobi.2011.02.002.

58. Khan, K. S., Joergensen, R. G. (2006). Microbial C, N, and P relationships in moisture-stressed soils of potohar, Pakistan. Journal of Plant Nutrition and Soil Science, 169(4), 494-500. DOI 10.1002/jpln.200521904.

59. Kumari, A., Kapoor, K. K., Kundu, B. S., Mehta, R. K. (2008). Identification of organic acids produced during rice straw decomposition and their role in rock phosphate solubilization. Plant. Soil and Environment, 54(2), $72-$ 77. DOI 10.17221/2783-pse.

60. Pizzeghello, D., Berti, A., Nardi, S., Morari, F. (2011). Phosphorus forms and P-sorption properties in three alkaline soils after long-term mineral and manure applications in north-eastern Italy. Agriculture, Ecosystems and Environment, 141, 58-66. DOI 10.1016/j.agee.2011.02.011.

61. Elmaadawy, K. G., Ezz El Din, M., Khalid, A. M., Seifelnasr, A. A. (2015). Mineral industry in Egypt-part II non-metallic commodities-phosphate rocks. Journal of Mining World Express, 4, 1-18. DOI 10.14355/ mwe.2015.04.001.

62. Xiong, L. M., Lu, R. K., Truong, B. (1994). An evaluation of the agronomic potential of partially acidulated rock phosphates in calcareous soil. Fertilizer Research, 38, 205-212. DOI 10.1007/BF00749693.

63. Vassilev, N., Vassileva, M. (2003). Biotechnological solubilization of rock phosphate on media containing agro-industrial wastes. Applied Microbiology and Biotechnology, 61(5-6), 435-440. DOI 10.1007/s00253-003-1318-3.

64. Zapata, F., Zaharah, A. R. (2002). Phosphorus availability from phosphate rock and sewage sludge as influenced by the addition of water soluble phosphate fertilizer. Nutrient Cycling in Agroecosystems, 63, 43-48. DOI 10.1023/A:1020518830129. 
65. Biswas, D. R., Narayanasamy, G. (1998). Direct and residual effectiveness of partially acidulated phosphate rocks as P fertilizer in a cowpea-wheat cropping sequence. Journal of the Indian Society of Soil Science, 46(3), 406-412.

66. Rajan, S. S. S., O'Connor, M. B., Sinclair, A. G. (1994). Partially acidulated phosphate rocks: Controlled release phosphorus fertilizers for more sustainable agriculture. Fertilizer Research, 37(1), 69-78. DOI 10.1007/ BF00750675.

67. Agyin-Birikorang, S., Abekoe, M. K., Oladeji, O. O. (2007). Enhancing the agronomic effectiveness of natural phosphate rock with poultry manure: A way forward to sustainable crop production. Nutrient Cycling in Agroecosystems, 79(2), 113-123. DOI 10.1007/s10705-007-9101-y.

68. Zoysa, A. K. N., Loganathan, P., Hedley, M. J. (2001). Comparison of the agronomic effectiveness of a phosphate rock and triple superphosphate as phosphate fertilisers for tea (Camellia sinensis L.) on a strongly acidic ultisol. Nutrient Cycling in Agroecosystems, 59(2), 95-105. DOI 10.1023/A:1017516713145.

69. Ali, M., Ali, A., Tahir, M., Yaseen, M. (2012). Growth and yield response of hybrid maize through integrated phosphorus management. Pakistan Journal of Life and Social Sciences, 10(1), 59-66.

70. Mashori, N. M., Memon, M., Memon, K. S., Kakar, H. (2013). Maize dry matter yield and P uptake as influenced by rock phosphate and single super phosphate treated with farm manure. Soil and Environment, 32(2), 130-134.

71. Husnain, Rochayati, S., Sutriadi, T., Nassir, A., Sarwani, M. (2014). Improvement of soil fertility and crop production through direct application of phosphate rock on maize in Indonesia. Procedia Engineering, 83, 336-343. DOI 10.1016/j.proeng.2014.09.025.

72. Prabhu, N., Borkar, S., Garg, S. (2019). Phosphate solubilization by microorganisms. In: Meena, S. N., Naik, M. (Eds.), Advances in biological science research. pp. 161-176. UK: Academic Press Inc., Elsevier. DOI 10.1016/ b978-0-12-817497-5.00011-2.

73. Alori, E. T., Glick, B. R., Babalola, O. O. (2017). Microbial phosphorus solubilization and its potential for use in sustainable agriculture. Frontiers in Microbiology, 8, 971. DOI 10.3389/fmicb.2017.00971.

74. Kucey, R. M. N., Janzen, H. H., Leggett, M. E. (1989). Microbially mediated increases in plant-available phosphorus. Advances in Agronomy, 42, 199-228. DOI 10.1016/S0065-2113(08)60525-8.

75. Whitelaw, M. A., Harden, T. J., Helyar, K. R. (1999). Phosphate solubilisation in solution culture by the soil fungus penicillium radicum. Soil Biology and Biochemistry, 31(5), 655-665. DOI 10.1016/S0038-0717(98) 00130-8.

76. Wahid, F., Fahad, S., Danish, S., Adnan, M., Yue, Z. et al. (2020). Sustainable management with mycorrhizae and phosphate solubilizing bacteria for enhanced phosphorus uptake in calcareous soils. Agriculture, 10(8), 334. DOI 10.3390/agriculture10080334.

77. Richardson, A. E., George, T. S., Hens, M., Simpson, R. J. (2005). Utilization of soil organic phosphorus by higher plants. In: Turner, B. L., Frossard, E., Baldwin, D. S. (Eds.), Organic phosphorus in the environment, pp. 165-174. Cambridge, USA: CAB International Publishing.

78. Oberson, A., Joner, E. J. (2005). Microbial turnover of phosphorus in soil. In: Turner, B. L., Frossard, E., Baldwin, D. S. (Eds.), Organic phosphorus in the environment, pp. 133-164. Cambridge, USA: CAB International Publishing. DOI 10.1079/9780851998220.0133.

79. Brimecombe, M. J., De-Leij, F. A. A. M., Lynch, J. M. (2007). Rhizodeposition and microbial populations. In: Pinton, R., Varanini, Z., Nannipieri, P. (Eds.), The rhizosphere biochemistry and organic susbstances at the soilplant interface, pp. 73-109. Boca Raton, FL: CRC Press.

80. Sharif, M., Khan, M., Azim Khan, M., Wahid, F., Marwat, K. B. et al. (2015). Effect of rock phosphate and farmyard manure applied with effective microorganisms on the yield and nutrient uptake of wheat and sunflower crops. Pakistan Journal of Botany, 47(SI), 219-226.

81. Sashidhar, B., Podile, A. R. (2010). Mineral phosphate solubilization by rhizosphere bacteria and scope for manipulation of the direct oxidation pathway involving glucose dehydrogenase. Journal of Applied Microbiology, 109(1), 1-12. DOI 10.1111/j.1365-2672.2009.04654.x.

82. Wahid, F., Sharif, M., Khan, M. A., Khan, M. J. (2016). Status and phosphorus solubilization potential of bacteria and arbuscular mycorrhizal fungi isolated from various locations of khyber pakhtunkhwa province. Pakistan Journal of Botany, 48(5), 2121-2130. 
83. Smith, S. E., Read, D. J. (2008). Mycorrhizal Symbiosis. In: Soil science society of america journal, 3rd ed., vol. 137. Academic Press Inc., Elsevier. DOI 10.2136/sssaj2008.0015br.

84. Brundrett, M. C. (2009). Mycorrhizal associations and other means of nutrition of vascular plants: Understanding the global diversity of host plants by resolving conflicting information and developing reliable means of diagnosis. Plant and Soil, 320(1-2), 37-77. DOI 10.1007/s11104-008-9877-9.

85. Marschner, H. (1995). Mineral nutrition of higher plants. In: Mineral nutrition of higher plants, 2 nd ed. Academic Press. DOI 10.1016/B978-012473542-2/50017-1.

86. Wahid, F., Sharif, M., Fahad, S., Adnan, M., Khan, I. A. et al. (2019). Arbuscular mycorrhizal fungi improve the growth and phosphorus uptake of mung bean plants fertilized with composted rock phosphate fed dung in alkaline soil environment. Journal of Plant Nutrition, 42(15), 1760-1769. DOI 10.1080/ 01904167.2019.1643371.

87. Smith, S. E., Dickson, S., Smith, F. A. (2001). Nutrient transfer in arbuscular mycorrhizas: How are fungal and plant processes integrated? Functional Plant Biology, 28(7), 685. DOI 10.1071/pp01033.

88. Rausch, C., Daram, P., Brunner, S., Jansa, J., Laloi, M. et al. (2001). A phosphate transporter expressed in arbuscule-containing cells in potato. Nature, 414(6862), 462-465. DOI 10.1038/35106601.

89. Schalamuk, S., Cabello, M. (2010). Arbuscular mycorrhizal fungal propagules from tillage and no-tillage systems: Possible effects on glomeromycota diversity. Mycologia, 102(2), 261-268. DOI 10.3852/08-118.

90. Kahiluoto, H., Ketoja, E., Vestberg, M. (2000). Creation of a non-mycorrhizal control for a bioassay of AM effectiveness. Mycorrhiza, 9(5), 241-258. DOI 10.1007/p100009989.

91. Shi, Z., Zhang, J., Lu, S., Li, Y., Wang, F. (2020). Arbuscular mycorrhizal fungi improve the performance of sweet sorghum grown in a Mo-contaminated soil. Journal of Fungi, 6(2), 44. DOI 10.3390/jof6020044.

92. Naher, U. A., Othman, R., Panhwar, Q. A. (2013). Culturable total and beneficial microbial occurrences in longterm nutrient deficit wetland rice soil. Australian Journal of Crop Science, 7, 1848-1853. DOI 10.3316/ INFORMIT.669187085781871.

93. Bindraban, P. S., Dimkpa, C. O., Pandey, R. (2020). Exploring phosphorus fertilizers and fertilization strategies for improved human and environmental health. Biology and Fertility of Soils, 56(3), 299-317. DOI 10.1007/ s00374-019-01430-2.

94. Tian, J., Dippold, M., Pausch, J., Blagodatskaya, E., Fan, M. et al. (2013). Microbial response to rhizodeposition depending on water regimes in paddy soils. Soil Biology and Biochemistry, 65, 195-203. DOI 10.1016/j. soilbio.2013.05.021.

95. Parewa, H. P., Meena, V. S., Jain, L. K., Choudhary, A. (2018). Sustainable crop production and soil health management through plant growth-promoting rhizobacteria. In: Role of rhizospheric microbes in soil: Stress management and agricultural sustainability, vol. 1, pp. 299-329. Singapore: Springer. DOI 10.1007/978-98110-8402-7_12.

96. Pellegrino, E., Bedini, S., Avio, L., Bonari, E., Giovannetti, M. (2011). Field inoculation effectiveness of native and exotic arbuscular mycorrhizal fungi in a Mediterranean agricultural soil. Soil Biology and Biochemistry, 43(2), 367-376. DOI 10.1016/j.soilbio.2010.11.002.

97. Rillig, M. C., Mummey, D. L. (2006). Mycorrhizas and soil structure. New Phytologist, 171(1), 41-53. DOI 10.1111/j.1469-8137.2006.01750.x.

98. Hallett, P. D., Feeney, D. S., Bengough, A. G., Rillig, M. C., Scrimgeour, C. M. et al. (2008). Disentangling the impact of AM fungi versus roots on soil structure and water transport. Plant and Soil, 314(1-2), 183-196. DOI 10.1007/s11104-008-9717-y.

99. Wright, S. F., Green, V. S., Cavigelli, M. A. (2007). Glomalin in aggregate size classes from three different farming systems. Soil and Tillage Research, 94(2), 546-549. DOI 10.1016/j.still.2006.08.003.

100. Patel, D. K., Archana, G., Kumar, G. N. (2007). Variation in the nature of organic acid secretion and mineral phosphate solubilization by citrobacter sp. DHRSS in the presence of different sugars. Current Microbiology, 56(2), 168-174. DOI 10.1007/s00284-007-9053-0.

101. Teodosieva, R., Yakimova Bojinova, D., Ivanova, R., Bojinova, D., Nedialkova, K. et al. (2006). Rock phosphate solubilization by soil bacteria. Journal of the University of Chemical Technology and Metallurgy, 41(3), 297-302. 
102. Kaur, G., Reddy, M. S. (2015). Effects of phosphate-solubilizing bacteria, rock phosphate and chemical fertilizers on maize-wheat cropping cycle and economics. Pedosphere, 25(3), 428-437. DOI 10.1016/s1002-0160(15) 30010-2.

103. Pereira, S. I. A., Castro, P. M. L. (2014). Phosphate-solubilizing rhizobacteria enhance Zea mays growth in agricultural P-deficient soils. Ecological Engineering, 73, 526-535. DOI 10.1016/j.ecoleng.2014.09.060.

104. Siddiqui, Z. A. (2006). PGPR: Prospective biocontrol agents of plant pathogens. In: Siddiqui, Z. A. (Ed.), PGPR: Biocontrol and biofertilization, 1st ed., pp. 111-142. Netherlands: Springer. DOI 10.1007/1-4020-4152-7_4.

105. Kennedy, A. C., Kremer, R. J. (1996). Microorganisms in weed control strategies. Journal of Production Agriculture, 9(4), 480-485. DOI 10.2134/jpa1996.0480.

106. Whipps, J. M. (2001). Microbial interactions and biocontrol in the rhizosphere. Journal of Experimental Botany, 52(1), 487-511. DOI 10.1093/jxb/52.suppl_1.487.

107. Weller, D. M. (1988). Biological control of soilborne plant pathogens in the rhizosphere with bacteria. Annual Review of Phytopathology, 26(1), 379-407. DOI 10.1146/annurev.py.26.090188.002115.

108. Nagórska, K., Bikowski, M., Obuchowski, M. (2007). Multicellular behaviour and production of a wide variety of toxic substances support usage of bacillus subtilis as a powerful biocontrol agent. Acta Biochimica Polonica, 54(3), 495-508. DOI 10.18388/abp.2007_3224.

109. Chakraborty, U., Chakraborty, B., Basnet, M. (2006). Plant growth promotion and induction of resistance in camellia sinensis by bacillus megaterium. Journal of Basic Microbiology, 46(3), 186-195. DOI 10.1002/ jobm.200510050.

110. Zhang, L., Fan, J., Ding, X., He, X., Zhang, F. et al. (2014). Hyphosphere interactions between an arbuscular mycorrhizal fungus and a phosphate solubilizing bacterium promote phytate mineralization in soil. Soil Biology and Biochemistry, 74, 177-183. DOI 10.1016/j.soilbio.2014.03.004.

111. Zabihi, H. R., Savaghebi, G. R., Khavazi, K., Ganjali, A., Miransari, M. (2010). Pseudomonas bacteria and phosphorous fertilization, affecting wheat (Triticum aestivum L.) yield and P uptake under greenhouse and field conditions. Acta Physiologiae Plantarum, 33(1), 145-152. DOI 10.1007/s11738-010-0531-9.

112. Kohler, J., Caravaca, F., Carrasco, L., Roldan, A. (2006). Contribution of pseudomonas mendocina and glomus intraradices to aggregate stabilization and promotion of biological fertility in rhizosphere soil of lettuce plants under field conditions. Soil Use and Management, 22(3), 298-304. DOI 10.1111/j.1475-2743.2006.00041.x.

113. Andrade, G., Linderman, R. G., Bethlenfalvay, G. J. (1998). Bacterial associations with the mycorrhizosphere and hyphosphere of the arbuscular mycorrhizal fungus glomus mosseae. Plant and Soil, 202(1), 79-87. DOI 10.1023/ $\mathrm{a}: 1004397222241$.

114. Kobae, Y. (2019). Dynamic phosphate uptake in arbuscular mycorrhizal roots under field conditions. Frontiers in Environmental Science, 6, 159. DOI 10.3389/fenvs.2018.00159.

115. Artursson, V., Finlay, R. D., Jansson, J. K. (2006). Interactions between arbuscular mycorrhizal fungi and bacteria and their potential for stimulating plant growth. Environmental Microbiology, 8(1), 1-10. DOI 10.1111/j.14622920.2005.00942.x.

116. Sabannavar, S. J., Lakshman, H. C. (2009). Effect of rock phosphate solubilization using mycorrhizal fungi and phosphobacteria on two high yielding varieties of sesamum indicum L. World Journal of Agriculture Science, 5, 470-479. DOI 10.1111/j.1439-037x.2008.00338.x.

117. Bharadwaj, D. P., Alström, S., Lundquist, P. O. (2011). Interactions among Glomus irregulare, arbuscular mycorrhizal spore-associated bacteria, and plant pathogens under in vitro conditions. Mycorrhiza, 22(6), 437447. DOI 10.1007/s00572-011-0418-7.

118. Scheublin, T. R., Sanders, I. R., Keel, C., van der Meer, J. R. (2010). Characterisation of microbial communities colonising the hyphal surfaces of arbuscular mycorrhizal fungi. The ISME Journal, 4(6), 752-763. DOI 10.1038/ ismej.2010.5.

119. Leigh, J., Fitter, A. H., Hodge, A. (2011). Growth and symbiotic effectiveness of an arbuscular mycorrhizal fungus in organic matter in competition with soil bacteria. FEMS Microbiology Ecology, 76(3), 428-438. DOI 10.1111/j.1574-6941.2011.01066.x. 
120. Herman, D. J., Firestone, M. K., Nuccio, E., Hodge, A. (2012). Interactions between an arbuscular mycorrhizal fungus and a soil microbial community mediating litter decomposition. FEMS Microbiology Ecology, 80(1), 236247. DOI 10.1111/j.1574-6941.2011.01292.x.

121. Leigh, J., Hodge, A., Fitter, A. H. (2008). Arbuscular mycorrhizal fungi can transfer substantial amounts of nitrogen to their host plant from organic material. New Phytologist, 181(1), 199-207. DOI 10.1111/j.14698137.2008.02630.x.

122. Arzanesh, M. H., Alikhani, H. A., Khavazi, K., Rahimian, H. A., Miransari, M. (2010). Wheat (Triticum aestivum L.) Growth enhancement by Azospirillum sp. under drought stress. World Journal of Microbiology and Biotechnology, 27(2), 197-205. DOI 10.1007/s11274-010-0444-1.

123. Toro, M., Azcon, R., Barea, J. (1997). Improvement of arbuscular mycorrhiza development by inoculation of soil with phosphate-solubilizing rhizobacteria to improve rock phosphate bioavailability ((sup32)P) and nutrient cycling. Applied and Environmental Microbiology, 63(11), 4408-4412. DOI 10.1128/aem.63.11.44084412.1997.

124. Abbas-Zadeh, P., Saleh-Rastin, N., Asadi-Rahmani, H., Khavazi, K., Soltani, A. et al. (2009). Plant growthpromoting activities of fluorescent pseudomonads, isolated from the Iranian soils. Acta Physiologiae Plantarum, 32(2), 281-288. DOI 10.1007/s11738-009-0405-1.

125. Bianciotto, V., Andreotti, S., Balestrini, R., Bonfante, P., Perotto, S. (2009). Extracellular polysaccharides are involved in the attachment of azospirillum brasilense and rhizobium leguminosarum to arbuscular mycorrhizal structures. European Journal of Histochemistry, 45(1), 39. DOI 10.4081/1612.

126. Kim, K., Yim, W., Trivedi, P., Madhaiyan, M., Boruah, H. P. D. et al. (2009). Synergistic effects of inoculating arbuscular mycorrhizal fungi and methylobacterium oryzae strains on growth and nutrient uptake of red pepper (Capsicum annuum L.). Plant and Soil, 327(1-2), 429-440. DOI 10.1007/s11104-009-0072-4.

127. Artursson, V., Finlay, R. D., Jansson, J. K. (2005). Combined bromodeoxyuridine immunocapture and terminalrestriction fragment length polymorphism analysis highlights differences in the active soil bacterial metagenome due to glomus mosseae inoculation or plant species. Environmental Microbiology, 7(12), 1952-1966. DOI 10.1111/j.1462-2920.2005.00868.x.

128. Hameeda, B., Rupela, O. P., Reddy, G., Satyavani, K. (2006). Application of plant growth-promoting bacteria associated with composts and macrofauna for growth promotion of pearl millet (Pennisetum glaucum L.). Biology and Fertility of Soils, 43(2), 221-227. DOI 10.1007/s00374-006-0098-1.

129. Meyer, J. R., Linderman, R. G. (1986). Response of subterranean clover to dual inoculation with vesiculararbuscular mycorrhizal fungi and a plant growth-promoting bacterium, Pseudomonas putida. Soil Biology and Biochemistry, 18(2), 185-190. DOI 10.1016/0038-0717(86)90025-8.

130. Bidondo, L. F., Bompadre, J., Pergola, M., Silvani, V., Colombo, R. et al. (2012). Differential interaction between two Glomus intraradices strains and a phosphate solubilizing bacterium in maize rhizosphere. Pedobiologia, 55(4), 227-232. DOI 10.1016/j.pedobi.2012.04.001.

131. Yaseen, M., Ahmed, W., Shahbaz, M. (2013). Role of foliar feeding of micronutrients in yield maximization of cotton in punjab. Turkish Journal of Agriculture and Forestry, 37, 420-426. DOI 10.3906/tar-1206-56.

132. Saxena, J., Saini, A., Ravi, I., Chandra, S., Garg, V. (2015). Consortium of phosphate-solubilizing bacteria and fungi for promotion of growth and yield of chickpea (Cicer arietinum). Journal of Crop Improvement, 29(3), 353-369. DOI 10.1080/15427528.2015.1027979.

133. Cao, J., Huang, Y., Wang, C. (2015). Rhizosphere interactions between earthworms (Eisenia fetida) and arbuscular mycorrhizal fungus (Funneliformis mosseae) promote utilization efficiency of phytate phosphorus in maize. Applied Soil Ecology, 94, 30-39. DOI 10.1016/j.apsoil.2015.05.001.

134. Verma, P., Yadav, A. N., Khannam, K. S., Panjiar, N., Kumar, S. et al. (2015). Assessment of genetic diversity and plant growth promoting attributes of psychrotolerant bacteria allied with wheat (Triticum aestivum) from the northern hills zone of India. Annals of Microbiology, 65(4), 1885-1899. DOI 10.1007/s13213-014-1027-4. 